811.163.41'38

811.163.41'42

https://doi.org/10.18485/sj.2019.24.1.20

САЊА М. КУЉАНИН

Универзитет у Источном Сарајеву

Филозофски факултет Пале
Оригинални научни рад

Примљен: 09. 10. 2018.

Прихваћен: 15. 01. 2019.

\title{
ЕКСПРЕСИВНОСТ ЈЕЗИЧКИХ ЈЕДИНИЦА У ФУНКЦИЈИ ИЗРАЖАВАЮА РЕВОЛУЦИОНАРНИХ ПРИНЦИПА МЛАДОБОСАНАЦА
}

\begin{abstract}
Циљ рада је да се из текстова младобосанаца ексцерпирају и анализирају, на формално-семантичком плану, примјери у чијој су структури заступљене језичке јединице експресивне семантике, са статусом екскламативности, а у функцији изражавања револуционарних идеја младобосанаца.
\end{abstract}

Кључне ријечи: младобосанци, екскламативност, емоционалност, експресивност, интензификација, патос.

\section{1. О МЛАДОБОСАНЦИМА}

О младобосанцима и Гаврилу Принципу пише се већ више од стотину година, па и ове, 2018, на стогодишњицу побједе у Великом рату, пишемо у славу побједника, а сигурни смо да ће они и у будућности бити тема бројних радова, јер „није било одавно поколење које је више и смелије маштало и говорило о животу, уживању и слободи, а које је мање имало од живота, горе страдало, теже робовало и више гинуло". Била је то цијела једна генерација, углавном двадесетогодишњака, који су били спремни у револуционарној борби против аустроугарске окупације, за национално и социјално ослобођење, дати

*sanja.kuljanin@ffuis.edu.ba 
и свој млади живот. Дјеловали су окупљени око покрета Млада Босна ${ }^{1}$, на два плана, на књижевном и револуционарном, али обједињена истим циљем: борбом за класно и национално ослобођење. Не само да су били противници окупационе власти и заступници српског националног ослобођења и уједињења него су били и против „српске малокрвности, идејног беспућа и недостатка националног поноса и прегнућа” (СП, 10), против „безидејности и устајалости мртве и непокретне средине" (СП, 150), како то у тексту о Богдану Жерајићу потврђује Владимир Гаћиновић: „Српска површина дозива ми у памет познати узвик Микеланђела над обореношћу и свезаношћу његове отаџбине: 'Лепо је спавати, још лепше бити од камена док трају беда и срам, ништа не видети, не осећати ништа то је моја срећа, дакле не буди ме, ах! говорите тише!'” (СП, 50). Били су дубоко увјерени у своје политичко опредјељење и револуционарну дјелатност, били су симбол отпора против аустроугарске власти, и не само то, они су, у ствари, правда и слобода за све потлачене, понижене, обесправљене, јер нису затварали очи пред неправдом и људским лицемјерјем и сматрали су да се треба борити за ослобођење поробљеног народа. У свему томе невјероватна је њихова снага да се да властити живот за такве вриједности, да се за своју идеју умре. Смисао њиховог живота је „у спремности на жртву у ономе лазаревском 'умримо да свагда живи будемо', у оном да је царство земаљско пролазно, а Царство Небеско вечно, у ономе да се не размишља против какве се силе иде, него каква се светиња брани, у најдубљој смелости да се искорачи из себе ка Вечном" (Димитријевић 2013), чиме су доказали „своју способност за живот приправношћу за смрт”, јер се, сматрали су, може само „умирући створити ново време и нов принцип у својој отаџбини" (СП, 56). Сви су они до краја били посвећени револуционарној борби за национално и социјално ослобођење, за живот достојан човјека: и Богдан Жерајић, и Недељко Чабриновић, и Вељко Чубриловић, и Владимир Гаћиновић, и Данило Илић, и Боривоје Јевтић, и Димитрије Митриновић, и Милош Видаковић, и многи, многи други... А међу њима и Гаврило Принцип, „тих, скроман, из сиротињске куће, дечак врабац” (Димитријевић 2013), један од оних храбрих Срба који су робијали и у тамницама умирали, који су свој живот дали за истину, слободу и отаџбину, који су храбро пали за боље сутра свог народа. Гаврило је жртвовао свој живот да би показао револт због покоравања аустроугарском окупатору, јер се није могао помирити са потлаченим положајем свог народа и своје отаџбине.

На почетку 20. в., упоредо с револуционарним тенденцијама и покретима, и у књижевности је, у складу с тим, отпочео јадан вид стваралаштва, почела је

${ }^{1}$ Сам назив Млада Босна настао је по угледу на Мацинијеву Младу Италију. „Мацинијеве идеје - да омладина мора бити основна снага у ослобођењу своје груде, да она мора створити људе новога кова, спремне на највеће жртве, утицале су много на младобосанце у првим годинама њиховог рада и стварања програма" (Дедијер 1966: 297). 
да се развија друштвено ангажована књижевност. То је био начин да се изрази незадовољство због обесправљености и потлачености човјека. Зато је она заснована на реалистичком поступку, па може имати и документарну вриједност. Тако су и младобосанци, између осталог, дјеловали и своје текстове врло често стављали у функцију прокламовања политичких идеја. Они су и сами учествовали у друштвеним догађајима и настојали да промијене постојеће друштвено стање, па је њихова умјетничка и интелектуална дјелатност уткана у њихове револуционарне идеје и ангажовање за стварање новог, праведног друштва. Међутим, „књижевни нараштај Младе Босне није стигао да потврди своје праве стваралачке способности (...); у годинама у којима срећније генерације тек почињу да стварају, многи писци Младе Босне заувек су се опростили од књижевности и живота" (СП 2, 729). Били су веома наклоњени књижевности, имали су и своје претече и узоре. Заносили су се пјесмама Милана Ракића, Јована Дучића, Симе Пандуровића, Милутина Бојића, Владислава Петковића Диса, Вељка Петровића. Посебно интересовање показали су за прозна дјела Петра Кочића², Светозара Ћоровића, Исидоре Секулић и других.

Младобосанци су се у свом књижевном раду бавили разноврсним темама: у програмским текстовима они између осталог пишу и о науци, филозофији, журналистици, књижевности и култури, а свакако су теме њихових радова друштво, политика и историјска збивања. У својим текстовима они износе разноврсне ставове и идеје у вези са друштвено-политичком ситуацијом, од констатовања чињеничног стања, преко тога зашто је стање такво, тј. преко узрочно-посљедичних тврдњи, па све до таквих у којима изјављују шта треба чинити. Такође настоје освијестити народ и посебно омладину, те је наглашено и начело патоса, односно емоција које се желе пробудити код читалаца, те се као карактеристике њихових текстова уочавају сугестивност, изражајност, аутентичност. А у овоме раду говорићемо о експресивности језичких јединица у њиховим текстовима, која се очитује у њиховом настојању да кроз различите облике стваралаштва искажу своја стремљења, расположења, циљеве. Издвојићемо језичке јединице и конструкције које у овом, можемо рећи револуционарном дискурсу, изражавају перцепцију стварности о којој младобосанци пишу или, друкчије речено, које су у функцији изражавања револуционарних

${ }^{2}$ Одломак из текста Јове Варагића свједочи о томе колико су младобосанци поштовали Кочићево дјело: „Док су најбољи синови Србије падали као жртве својих идеала по бојиштима, у то исто време помрчао је и ум најдостојнијем од најдостојнијих Срба у Босни и Херцеговини. Жртве се траже, жртве и падају, али је утешна појава да те жртве не падају узалуд. Помрчао је ум Петру Кочићу, али над његовом трагедијом улази светлост у умове многих, душе постају благородније и приступачније нашим великим задацима. Сва његова силна љубав, самопрегор, јединствено поштење, озаравају нас и подижу, и у моменту његова страдања они устају у свој сили пред нама. Ми у моменту осећамо колико смо дужни својој земљи и народу у дане који значе обрт, прелом из патријархалног у ново доба, које носи собом борбу, страсну и врелу, истина пуну тешких кушња, али достојну човека у пуном смислу те речи" (СП, 66). 
идеја и ставова младобосанаца у њиховим властитим текстовима, због чега, између осталог, такве језичке јединице доприносе наглашеној експресивности. Корпус чине текстови младобосанаца сабрани у књизи Споменица Младе Босне 1914-2014 (СП: Максимовић 2014).

\section{2. ЕКСПРЕСИВНОСТ}

Прије него што наведемо ексцерпиране примјере експресивних језичких јединица у функцији изражавања револуционарних идеја младобосанаца, рећи ћемо шта, у складу са дефинисањем у научној литератури, подразумијевамо под експресивношћу.

У Лингвистичком енциклопедијском рјечнику експресивност се дефинише као свеукупност семантичко-стилистичких обиљежја јединице језика која јој омогућују да долази у комуникативном чину као средство субјективног изражавања односа говорника према садржају или адресату говора (Тошовић 2004: 26). Може се рећи да она настаје као резултат прагматичне употребе језика чији је основни циљ изражавање емоционалног перлокутивног (позитивно или негативно обојеног) односа субјекта говора према означеном и „инфицирање” тим односом адресата (Телија 1991: 35). Експресивним се називају текстови или њихови елементи који на основу сопствене форме у посебном обиму изражавају емоције и оријентацију говорног лица (Мецлер 2000: 201). Експресивност се назива и семантичком категоријом, која даје говору изражајност на рачун интеракције у садржајном дијелу језичке јединице, исказа, текста, оцјењивачког и емоционалног односа субјекта говора (лица које говори или пише) према ономе што се дешава у спољњем или унутрашњем свијету (Енциклопедија „Русский язык” 1997: 637-638). Најопштије може се одредити као изразита изражајност, која се остварује или конотативном семантичком структуром или нарочитом гласовном структуром. У ужем смислу, „под експресивношћу се подразумева постојање у семантици речи компонената којим се изражавају мера и степен особине неке појаве, при чему је неки аутори поистовећују са интензивношћу (Ристић 2004: 18).

У сваком случају, експресивизација као појачавање, истицање актуелног садржаја дискурса, проистиче из специфичне употребе језичких јединица субјекта говора, којима он изражава субјективни став и емоцију према одређеном садржају комуникације и објективној стварности. У овом случају ријеч је о ставу младобосанаца према историјско-друштвеним односима и свему ономе што смо већ навели као преокупацију њиховог дјеловања.

За анализу смо издвојили само примјере експресивно-емфатичких исказа, уз навођење различитих типова екскламативних реченица, као веома 
фреквентних и специфичних у анализираном корпусу, у чију су структуру инкорпориране разноврсне језичке јединице с експресивном семантиком.

\section{3. ЕКСПРЕСИВНО-ЕМФАТИЧКЕ КОНСТРУКЦИЈЕ}

У оквиру експресивно-емфатичких форми издвојили смо прије свега субјективне, емоционалне исказе који су, у складу с расположењем говорног субјекта и његовог односа према ономе што се дешава у спољњем или унутрашњем свијету, структурно и интонационо обиљежени. То првенствено подразумијева исказивање емоционалних стања и ставова говорног лица у вези са садржајем исказа и наглашавање или интензификацију одређених сегмената исказа неким језичким средством експресивне семантике, такође са становишта говорног субјекта. Издвојене језичке јединице функционишу као експресивно-емфатички изрази у складу са контекстом, тј. са социјално-политичком ситуацијом и револуционарним идејама младобосанаца.

\section{1. Екскламативне реченице}

Ова врста комуникативних исказа веома је фреквентна изражајна форма у функцији исказивања разноврсних идеја и ставова младобосанаца, а пошто је ријеч о револуционарно-идеолошкој тематици, у складу с тим је онда и избор лексике и језичких конструкција којима се изражавају револуционарне идеје и протест против постојећег стања, немирење са ситуацијом, борба по сваку цијену, спремност да се да и властити живот, због чега су такви искази изузетно емоционално обојени. Ову врсту реченичних конструкција, општепознато je, карактерише узвичник као интонациони маркер, а „ускличност је заправо облик наглашавања снаге израза - дочарава осјећаје, душевно стање говорника, наглашава мисао и усмјерава перцепцију исказа" (Багић 2012: 90). Слиједе примјери екскламативних реченица из анализираног корпуса, уз навођење њихових основних карактеристика које доприносе експресивности исказа:

На демократизаџији наука у нас се, на жалост, врло мало радило. Као да смо ми неки изузетак, па нам не треба научних и философских књига! И као да нас не треба да занимају опћа размишььња о појавама природе, о човјеку и његову друштву, о смислу и вриједности нашег моралног живота и дјеловања! (СП, 124)

Издвојени примјери екскламативних реченица свједоче о ставовима младобосанаца у вези са стањем у науци и култури. Послије једне декларативне реченице и у први моменат мирне констатације о стању у науци, на чијој се демократизацији врло мало ради, слиједи непомирљив став у вези с тим. Аутор исказује своје неслагање с таквом ситуацијом, а свој револт и веома јаке емоције издваја у двије засебне екскламативне реченице са узвичником као уобичајеним маркером њихове интонационе експресивности. Контекст у 
којем су употријебљене ове реченице, појачана интонација и конструкције са сложеним поредбеним везником као да интензивирају експресивност, што ове екскламативне реченице издваја од неутралних изјавних реченица, чији би садржај нпр. гласио: На демократизаиији наука унас се, на жалост, врло мало радило, а нисмо ни ми неки изузетак, и нама треба научних и философских књига, и нас занимају опћа размишљања о појавама природе... При наведеној трансформацији уочавамо трансфер потврдне форме (као да смо ми неки изузетак) у одричну (нисмо ни ми неки изузетак) и, обратно, одричне (па нам не треба научних и философских књига) у потврдну (и нама треба научних и философских књига), те можемо констатовати да реченична конструкција са сложеним поредбеним везником као да функционише као реторичко питање, нпр. са ријечцом зар: Зар смо ми неки изузетак, па нам не треба научних и философских књига! Зар и нас не треба да занимају опћа размишљаға о појавама природе..., што такође доприноси појачаном изразу. Осим тога, карактеристика овог контекста је и употреба облика личне замјенице $м и$, у функцији социјалних експресива, којима се изражава „намера говорника да одабраном употребом језичких средстава постигне функционално-стилски ефекат са илокуцијском снагом изазивања емотивног односа адресата према објекту комуникације" (Ристић 2004: 201), а то ми овдје је у значењу наша земља, отацбина, држава, наш народ. Такве језичке јединице су уједно и средство патоса, а у истој је функцији, у оваквом контексту, и експресивно-емфатичко обиљежје наведених екскламативних реченица.

То је срамота: да један човјек, који се хоће да зове образованим ичиели свој живот проведе искључиво и само у подмиривању и задовољавању нижих, тјелесних потреба, а да му никад ни на ум не пане задовољење виших, финијих потреба духа и разума! (СП, 125)

Садржај ове реченице повезан је са садржајем претходне, дакле и овдје је ријеч о лошем стању у култури због чега субјекат говора такође изражава своје велико незадовољство. Емфаза и патос су обиљежје и овог исказа, што га, заједно са његовим специфичним структурисањем, чини веома експресивном језичком јединицом. Специфичност овог примјера је у сљедећем: управна реченица је кратка и ефектна; њен субјекат је изражен демонстративном замјеницом средњег рода то, која има катафорску функцију, а зависна клауза с везником $\partial а$ експлицира садржај те катафорске замјенице. У функцији предикатива је лексема афективне оцјене, чиме се скреће пажња на садржај који слиједи, те појачава заинтересованост реципијента за катафорски садржај. Аутор текста управну реченицу од остатка садржаја издваја интерпункцијским знаком двије тачке, на чијем мјесту би, да није одмах наведено објашњење шта је то срамо-

${ }^{3}$ „Речца зар одлика је упитних исказа који садрже информацију о изневереној очекиваности супротне ситуације од оне на коју се односи садржај пропозиције...” (Пипер и др. 2005: 674). 
та, могао да стоји узвичник. Овакво интонационо и реченично конструисање резултат је великог незадовољства и веома јаких емоција говорног субјекта, те зато он жели исказати свој став и рећи за неку објективну стварност да је срамотна и прије него што детаљно информише читаоца о чему је ријеч. На тај начин жели да усмјери његову пажњу и појача радозналост да чује о чему је ријеч, те да и он, адресат, емоционално подржи став адресанта исказа.

Знања, познавања, културе! То је први симбол у томе новом Вјерују. Напоље, у слободу, у борбу! (СП, 141)

Овакве екскламативне реченице веома су експресивне, а то се овдје постиже неглаголским, максимално редукованим исказом - генитивним облицима и приједлошко-падежним акузативним конструкцијама именица, те лексемом напоље, која је одређена као „1. прилог (уз глаголе који означавају кретање)... и 2. (у служби узвика) оштра заповест некоме да се удаљи: ван!” (РМС 1967: 595). Овако елидирана структура резултат је веома јаких емоција говорног лица када он исказује само нужне дијелове којима се остварује комуникативна функција, али тако редуковане структуре могу се остварити само у контексту познатом и саговорнику/читаоцу. Пошто је ријеч о текстовима младобосанаца и пошто смо већ наводили екскламативне примјере из истог контекста, јасно нам је да је и овдје ријеч о изражавању незадовољства аутора текста у вези са стањем у култури и немогућности да се млади образују и шире своја знања и спознаје. Због свега тога они позивају да се изађе из те учмалости, да се по сваку цијену боре за свој положај, за бољи живот, једном ријечју за слободу. У том стању егзалтираности и побуне говорно лице потребу и жељу за знањем, познавањем, културом изражава само облицима генитива ових именица, а изоставља се глаголска лексема (желимо или треба нам знања...). У другом примјеру уз прилог напоље подразумијевао би се глагол изаћи (изађимо из таквог стања у слободу, у борбу, тј. боримо се, покренимо се, промијенимо садашњу ситуацију).

\section{...доста осуђивања, кажи шта да се ради, ко да ради, где да ради! (СП, 84)}

Експресивност овог исказа заснива се на императивном значењу. Прва лексема са императивном семантиком је прилог доста, али овдје у служби узвика („доста прил. 1.а. довољно, толико да не треба више... б. у великој количини или броју, много, пуно, превише ... 3. (у служби узвика) заповест, забрана којима се тражи, захтева престанак чега... РМС 1967: 748). Слиједи глаголски императив (кажи), а императив, познато је, у свој садржај укључује елементе директивног исказа „који подразумијева интерперсоналну комуникацију, директно или индиректно присутног адресата. Укључује и интенцију адресанта исказа да дјелује, утиче на понашање адресата наводећи га да дјелује у правцу или у складу са активношћу која се именује садржајем пропозиције таквог исказа" (Бабић 2015: 111). Овакав исказ производ је јаких 
емоција говорног лица, а цијела конструкција подразумијева значење: доста је било осуђивања, с тим треба престати и нешто конкретно урадити како би се промијенило стање које изазива незадовољство младобосанаца и потлаченог народа. Све то редуковано је у најкраћи могући исказ, што је потпуно у складу са револуционарним дискурсом, ставовима и реакцијама младобосанаца. Осим што је и ово један емоционално јак, експресиван и економичан исказ, он је специфичан и по томе што експлицира саговорника (кажи), који ће рећи шта треба да се ради, гдје и ко треба да ради, што асоцира на заједничко дјеловање младобосанаца да се већ једном нешто промијени.

Наглашене емоције и социјални експресиви средство су патоса у сљедећим примјерима, у којима су издвојени основни циљеви и тежње младобосанаца и разлози због којих они морају устати и борити се.

Ми с поштовањем и поносним одушевљенем поздрављамо оно срећно вријеме, кад ћемо моћи рећи да смо се идентифицирали на основи Слободе и Слободоумности. На основи Слободе и Слободоумности! (СП, 149)

И они, који су дошли да се хране нашим хлебом и уживају плодове које смо ми стекли крвљу својом и знојем својим, нису се удостојили да се на нас сажале и осмехну презирним осмехом надмоћнога! Ни једним презирним осмехом! (СП, 157)

У првом примјеру аутор изражава своју жељу да што прије дође срећно вријеме слободе и слободоумности. У његовом исказу то и јесте оно најбитније. Да би то и додатно експлицирао, субјекат говора појачава значај лексема које су носиоци управо тог најважнијег садржаја тако што их понавља и интонационо издваја, осамостаљује у екскламативни исказ, али ни то није довољно па аутор своју превелику жељу за животом у слободи и слободоумности наглашава и писањем тих заједничких именица великим почетним словом, тј. за афективно појачавање овдје су употријебљене и графостилеме. У другој реченици говорно лице изражава своје гнушање и презир према непријатељима који су окупирали његову земљу и са неограниченом дрскошћу и безосјећајношћу тлаче народ и узимају му оно што је с муком стечено, са омаловажавањем и без имало стида. Емоције које су због свега тога потпуно савладале говорника производе интонационо веома појачан исказ, маркиран узвичником. Осим тога, емоција и узбуђеност утичу и на уобичајени ред ријечи у именичким синтагмама (крвљу својом и знојем својим), гдје долази до инверзије, тј. замјене мјеста именице и њеног конгруентног атрибута, чије се значење у постпозицији појачава. Резултат тога је интонациона и стилистичка маркираност синтагме, али и наглашавање садржаја атрибута, поготово што је овдје у обје синтагме у функцији атрибута придјевска присвојна замјеница $c в о j, ~-a,-e$, јер је ријеч о припадању субјекту говора, израженом опет социјалним експресивом ми, тј. ријеч је о народу и о младобосанцима, који једино имају снаге и храбрости да укажу на изузетно тежак положај народа и његову обесправљеност. У емоционално набијеној ситуацији аутор, као и у претходном случају, дијелове с краја 
реченице понавља у екскламативном неглаголском исказу, те тако привлачи пажњу на њега и доприноси стварању патетичног тона.

... то су они „огњевити људи” који презиру ситне материјалне користи, дижу се до висине хероја, заталасавају људску пучину, стварају историју! (СП, 80)

Наведеном реченичном конструкцијом исказан је став говорног лица према оним, како каже, „огњевитим” људима, какви су управо младобосанци, и према вриједностима какве имају такви људи - презирање материјалне користи, спремност за борбу и велике промјене, за стварање историје. Екскламативност произлази из емоција говорног лица које са усхићењем подржава вриједности које карактеришу те „огњевите” људе, младобосанце. А све што им се приписује исказано је адекватним лексемама у оквиру кратких, ефектних координираних копулативних реченица, које су у атрибутској функцији према управној реченици. Предикати су изражени презентом, што појачава убијеђеност у реализацију њиховог садржаја у актуелном тренутку. Осим тога, експресивности доприноси и градација у оквиру ове сложене реченице. Наиме, клаузе се налазе у својеврсном градационом низу, јер представљају скалу нарастања значења, у функцији изражавања ауторовог става о дјеловању револуционара, младобосанаца. Они, прво, уочавају и презиру све што је негативно у друштву, желе да се промијени таква ситуација и дижу се, тј. крећу у акцију, али утичу и на остале да се пробуде и промијене свој положај и тако, на крају, ти „огњевити” људи стварају историју. Свака клауза представља један степен више у том процесу дјеловања једног револуционара, управо као што је случај и са Гаврилом Принципом и осталим младобосанцима: они се нису мирили са неприхватљивим стањем човјека у њиховом друштву и времену, јавно су исказивали свој револт, активно дјеловали, ширили идеје о неопходности промјена, револуције, нису жалили ни живот свој дати.

Бављење младобосанаца и књижевноумјетничким радом потврђују сљедећи примјери:

Ax, а наша јадна приповијетка! Добар дио савремене и огроман дио старије приповијетке има мало заједничког са умјетношћу! (СП, 167)

Већ смо наводили примјере у којима младобосанци изражавају незадовољство стањем у науци и култури, а овдје је ријеч о стању у књижевноумјетничком стваралаштву, конкретно у приповијеци тога времена, за коју аутор сматра да нема велику умјетничку вриједност. Своје емоције, тј. своје жаљење због таквог стања, аутор изражава двјема екскламативним реченицама. Више је елемената који доприносе ефектности и изразитој експресивности првог, редукованог, неглаголског исказа. Прије свега то је узвик ах у иницијалном положају, који нас уводи у емоционално стање говорног лица, а затим ту су и атрибути - присвојна придјевска замјеница наш, - $a$, -e, опет као социјални експресив, и придјев афективне оцјене јадна, чији семантички садржај указује 
на осјећања субјекта говора у вези са стањем у књижевности. Узвик има катафоричку функцију и он у моменту када је говорник у посебном емоционалном стању „преноси неки садржај у најједноставнијем облику” (Белић 1958: 79). Њиме се, дакле, прво преноси емоција, а затим се именичком синтагмом наговјештава шта је у ствари проузроковало такву емоцију. Детаљнији катафорички садржај смјештен је у другој реченици и тек тада имамо и потпуну информацију о томе шта је изазвало такву реакцију субјекта говора. На крају ове реченице такође је узвичник као интонациони маркер, јер она и јесте екскламативна само по појачаној интонацији као посљедици говорниковог узбуђења, а садржај реченице сам по себи има обавјештајну комуникативну вриједност.

\section{2. Екскламативне реченице са замјеничко-прилошким интензификаторима}

Претходне примјере екскламативних реченица у узвичне комуникативне сврставамо према интонационо-експресивним карактеристикама, чиме је, у ствари, дезактуелизована њихова примарна комуникативна функција, те оне „Постају средство експресивне синтаксе јер изражавају неку од језичких функција модализованих експресивним ставом, емоцијама или директивношћу, чиме залазе у оквире поља екскламативних конструкција" (Бабић 2010: 101-102). Екскламацији у сљедећим примјерима доприносе, осим интонације, неке замјеничко-прилошке лексеме које улазе у њихову структуру и поједине реченичне чланове интензификују у смислу квалификације / квантификације. Издвојили смо примјере у којима такву функцију имају прилози колико и тако и замјеница какав, $-a,-o$, а у једном од примјера имамо и узвик, као јединицу експресивне семантике, специфичну за екскламативне исказе:

Колико ли је поклоника из свих крајева наше земье свратило у ову кућу где су ковани хајдучки и слободарски планови! (СП, 105); Колико некултуре и јада у тој препотопној логици! (СП, 148); Тако се мало пажње и признањ п поклонило човјеку који би се у јачем, зрелијем народу држао мислиоцем достојним сваке пажње! (СП; 229). Ах! Каква је тишина била у нашим сриима и колико је било жалости у нашем снисхођењу према оним који су за нас имали увек бич и тамницу! (СП, 156)

У наведеним примјерима максимализован је садржај оног реченичног дијела на који се односи интензификаторска лексема, која је у свим реченицама у иницијалној позицији. Прилог колико у нашем првом примјеру подразумијева значење веома много/изузетно много, чиме аутор жели нагласити да је небројено много људи свраћало у ту кућу (а ријеч је о кући револуционара Воје Танкосића), гдје су ковани слободарски планови, због чега говорно лице изражава велико задовољаство. У сљедећем примјеру прилошка лексема колико, у оквиру неглаголског исказа, интензификује генитивну супстантивну координирану синтагму (некултуре и јада) тако што уноси значење невјеро- 
ватно је колико је ту некултуре и јада. Тиме аутор износи свој став у вези са изразитом заступљеношћу садржаја који се односи на наведене лексеме и своје незадовољство и неслагање са постојећом ситуацијом и превазиђеним идејама.

Младобосанци имају и изражавају свој став и према непоштовању оних људи који дјелују позитивно у друштву, издвајају се својим дјеловањем и радом за добробит државе, а она им не узвраћа на одговарајући начин. Не поклања им се пажња и не даје заслужено признање, као што се то чини, како аутор каже, „у јачем и зрелијем народу”. Овакав њихов став исказан је реченицом у којој прилог тако, такође у иницијалној позицији, учествује у интензификацији одређеног реченичног члана. Овдје је интензификована квалификација изражена придјевом мало, у смислу да се појачава заступљености њеног садржаја до максималног степена (Тако се мало пажње и признања поклонило човјеку...). Тиме се постиже много виши степен емоционалности, односно експресивности, што се у неутралном исказу, без интензификаторске лексеме тако, не уочава, па у исказу Мало се пажње и признања поклонило човјеку... емотивни став говорника није испољен.

Посљедњи примјер у овој групи има велику експресивну вриједност, чему осим замјенице какав, - $a,-o$, са значењем невјероватна тишина, и прилога колико, који имплицира значење превише/невјероватно много жалости, много доприноси и узвик $a x$, издвојен узвичником, у позицији испред тог примјера. Тим узвиком аутор експлицира изузетно јаке емоције, толико јаке да их је он морао изразити и прије него што нас је упознао са разлозима који производе таква његова осјећања. Зато уочавамо да овај узвик има катафоричку функцију, а реченица која слиједи јесте управо тај катафорички садржај, тј. оно што је проузроковало тако јаке емоције говорног лица или аутора текста. Он испољава незадовољство, тугу, гњев, разочараност због тога што се у држави не реагује на тешку ситуацију у друштву и веома тежак положај народа, а поготово је аутор незадовољан помирљивим ставом према онима који су, како каже, „за нас имали увек бич и тамницу”. И у овој реченици имамо примјере употребе социјалних експресива, облике личне замјенице $м и$ и присвојне наш, - $a$, -e, којима се појачава патос и подразумијева ситуација у којој се налази и сам аутор.

У реченицама из претходне групе примјера говорно лице или субјекат говора исказује различита осјећања и веома јаке емоције, појачаном интонацијом, али овдје су веома значајне и замјеничко-прилошке језичке јединице, којима се интензификује сегмент са квантификованом семантиком до максималног степена. У нашим се примјерима формантима колико, тако и какав, - $a,-o, \mathrm{y}$ иницијалном положају у реченици, „на референцијалну подлогу надограђује интензивирање садржаја неког реченичног дијела и исказује емотивно стање 
или став говорника" (Бабић 2010: 107). Наведене језичке јединице са експресивном функцијом коначно своје значење, у ствари, добијају зависно од контекста у којем су употријебљене и од тога који је реченични члан њима обухваћен. Основна им је улога у реченици или исказу да максимално интензификују тај реченични дио, а цијели такав синтаксичко-семантички склоп настаје као посљедица веома јаких емоција говорног лица.

\section{4. ЗАКЉУЧАК}

Као експресивне језичке јединице у функцији појачавања актуелног садржаја, конкретно у функцији изражавања револуционарних идеја младобосанаца, у овоме смо раду издвојили експресивно-емфатичке форме којима су младобосанци исказали своје емоције и ставове у вези са социјално-политичком ситуацијом и својим идејама и принципима. Будући да је ријеч о револуционарно-идеолошкој тематици, у складу с тим је онда и избор лексике и језичких конструкција којима се изражавају револуционарне идеје и протест против постојећег стања, немирење са ситуацијом, борба по сваку цијену, спремност да се да и властити живот, због чега су такви искази изузетно емоционално обојени. Због свега наведеног, оваквом дискурсу у потпуности одговарају анализиране експресивно-емфатичке конструкције, у оквиру којих смо издвојили екскламативне форме. Таквим конструкцијама наглашавају се осјећања и преокупације говорног лица, аутор изражава свој револт и веома јаке емоције, а интонациона експресивност означена је узвичником као уобичајеним маркером таквих исказа. Осим тога, у ексцерпираним реченицама, у складу са контекстом, употријебљене су и језичке јединице као средство патоса и емфазе, нпр.: лична замјеница ми и присвојне замјенице $н а ш,-a$, -е и свој, - $a$, -е у функцији социјалног експресива, лексеме афективне оцјене, лексеме у служби узвика, максимално редуковани искази, те и друге интонационе и реченичне конструкције, нпр. са императивним значењем, затим инверзија у оквиру именичке синтагме, тј. замјена мјеста именице и њеног конгруентног атрибута, градација у оквиру сложене реченице и др. У оквиру екскламативних конструкција експресивност појачавају, осим интонације, неке замјеничко-прилошке лексеме које поједине реченичне чланове интензификују у смислу квалификације / квантификације, а ту функцију у нашим примјерима имају прилози колико и тако и замјеница какав, $-a,-o$. Интензификација одређених сегмената исказа тим лексемама имплицира значење веома/изузетно/невјероватно много или, друкчије речено, одређена квалификација заступљена је у максималом степену, уз испољавање емоционалног става говорног лица. Оваквим формама, како су показали ексцерпирани примјери, младобосанци исказују, између осталог, и своје ставове у вези са стањем у науци и култури, 
књижевноумјетничком стваралаштву, што свједочи о томе да су то били образовани младићи, интелектуалци, који су жељели просперитет своме народу, али прије свега слободу и слободоумност и живот достојан човјека.

\section{ИЗВОРИ}

СП - Споменииа Младе Босне 1914-2014, књига I, приређивач проф. др Војислав Максимовић, Пале-Источно Сарајево: Српско просвјетно и културно друштво „Просвјета” и Завод за уџбенике и наставна средства Источно Сарајево, 2014.

\section{ЛИТЕРАТУРА}

Бабић 2010: М. Бабић, Огледи из прагматичке синтаксе, Источно Сарајево: Филозофски факултет Универзитета у Источном Сарајеву.

Бабић 2015: М. Бабић, Синтаксички и стилистички огледи, Београд: Јасен.

Багић 2012: K. Bagić, Rječnik stilskih figura, Zagreb: Školska knjiga.

Белић 1958: А. Белић, О језичкој природи и језичком развитку, књ. 1, Београд: Нолит.

Дедијер 1966: В. Дедијер, Сарајево 1914, Београд: Просвета.

Димитријевић 2013: Vladimir Dimitrijević, Gavrilo Princip i mladobosanci: ko hoće da živi, nek mre (na ponos i sećanje), <http:// udicazasrce. wordpress.com/2013/04/20/ (приступ: 20. 4. 2018).

Енциклопедија „Русский язык” 1997: Русский язык. Энциклопедия / Главный редактор Ф. П. Филин, Москва: Советская энциклопедия.

Мецлер 2000: Metzler Lexikon Sprache, Herausgegeben von Helmut Glück, Stuttgart - Weimar: Verlag J. B. Metzler.

Ристић 2004: С. Ристић, Експресивна лексика у српском језику, Београд: Институт за српски језик.

PMC 1967-1976: Речник српскохрватског књижевног језика, I-VI, друго фототипско издање, 1990, Нови Сад - Загреб: Матица српска - Матица хрватска.

Телија 1991: В. Н. Телия, Механизмы экспрессивной окраски языковых единиц, у: Человеческий фактор в языке, Москва: Наука, 36-66. 
Тошовић 2004: Бранко Тошовић, Експресивност, (према Лингв. энц. сл. 1990: 591, Лингвистический энциклопедический словарь. / Гл. редактор Ярцева В.Н. - Москва: Советская энциклопедия), http://www. rastko.rs/cms/files/books/49c94a2930469

\section{AUSDRUCKSKRAFT SPRACHLICHER EINHEITEN IN FUNKTION DES AUSDRUCKS REVOLUTIONÄRER PRINZIPIEN DER MITGLIEDER DES „JUNGES BOSNIEN”}

\section{Zusammenfassung}

In der Arbeit wurden die expressiv-betonten Einheiten, mit denen die Mitglieder des „Junges Bosnien” ihre Gefühle, Haltungen, Ideen und Prinzipien, im Bezug auf die damalige sozial-politischen Situation, ausgedrückt haben. Im Rahmen der expressiv-betonten Konstruktionen haben wir die Ausrufformen aussortiert, mit denen besonders starke Gefühle des Sprchers betont werden. Die Intonation des Ausdrucks wird druch ein Ausrufezeichen gekennzeichnet, das ein gewöhliches Merkmal solcher Aussagen ist. Außerdem wurden, im Einklang mit dem Kontext, auch sprachliche Einheiten benutzt, die ein Mittel des Pathoses oder der Emphase darstellen, wie z.B. das Personalpronomen wir, Possesivedeterminativeuneser/-e, mein/-ein Funktion der sozialen Audruckskraft, Lexeme der affektiven Einschätzung, maximal reduzierte Aussagen und auch andere Intonations- und Satzkonstruktionen, z.B. mit Imperativbedeutung, Inversionen bei der Nominalphrasen, d.h. die Veränderung des Platzes des Nomen und des kongrunten Attributs, Gradationen beim Komplexensatz und Ähnliches. Bei den Ausrufskonstruktionen verstärken auch die Pronomina- und adverbialen Lexemedie Ausdruckskraft, wenn sie die Einzelnen Satzmitglieder, im Sinn der Klassifizierung/Qvantifizierung intensivieren. Diese Funktion haben bei den expressiven Beispielen die Adverbien wie und so und das Interrogativespronominawas für ein/-e. Die Intensivierung einzelner Teile der Aussage impliziert bei den Lexemen die Bedeutung von sehr/außergewöhnlich/ unglaublich sehr, d.h. sie ist in der Maximlane Stufe vertreten, und kennzeichnet die Gefühle des Sprechers. Durch diese Formen drücken die Mitglieder des ,Junges Bosnien”, unter anderem, auch ihre eigenen Meinungen zu der Situationen in der Wissenschaft und Kultur und in der Literatur.

Schlüsselwörter: Junges Bosnien, Ausrufe, Emotionalität, Expressivität, Intensievierung, Pathos.

Sanja M. Kuljanin 